\title{
PERKEMBANGAN KEPURBAKALAAN DALAM MENUNJANG PROFIL KEARIFAN LOKAL \\ DI DAERAH MALUKU
}

\section{Nendisa}

Kebudayaan suatu masyarakat pada pokoknya berfungsi menghubungkan manusia dengan alam disekitarnya dan dengan masyarakat dimana manusia itu menjadi warga. Dengan teknologi yang dimiliki oleh masyarakat dimaksud, maka manusia dapat menyesuaikan diri dengan alam, atau dapat pula memanfaatkan alam untuk keperluan hidupnya. Selain itu dengan menghayati nilai-nilai serta norma-norma sosial yang berlaku maka manusia dapat hidup serasi dengan warga-warga lain dalam masyarakat tersebut.

Dalam segala hubungan di atas maka manusia dituntut untuk selalu berusaha dalam memperoleh kebahagiaan yang memuaskan hatinya. Untuk masyarakat tertentu, kebahagiaan tersebut seolah-olah sudah dicapai sepenuhnya dalam kehidupan yang dialaminya, sehingga masyarakat tersebut tidak berusaha untuk meningkatkannya sehingga menjadikan mereka sebagai masyarakat yang tradisionalistik atau statik, sebaliknya ada pula masyarakat lain yang berkeinginan akan kebahagiaan itu seakan tidak pernah dapat terpenuhi.

Masyarakat seperti itu senantiasa berusaha memperbaiki tarap kehidupannya dan memperbaharui cara memenuhi kebutuhan hidupnya untuk mendapatkan kebahagiaan pada tarap yang lebih tinggi dari yang pernah didapati sebelumnya. Masyarakat dengan kategori ini nampaknya lebih bersikap terbuka untuk menerima hal-hal yang baru, yang mungkin dapat memenuhi keinginannya dengan memberikan kemantapan serta kepuasan yang lebih besar, yang secara suka rela menerima perubahanperubahan tata kehidupannya, karena dianggap bahwa tiap perubahan akan membawa pada tarap kehidupan yang lebih baik sehingga terciptanya pola akulturasi budaya yang dapat diterima oleh seluruh masyarakat pendukungnya yang terlihat dalam tatanan adat yang berlangsung. 
Seperti halnya daerah Maluku yang memiliki keanekaragaman budaya tradisional yang pada kenyataannya masih tetap dipertahankan keberadaannya setelah melalui proses penyesuaian dengan bentukan budaya baru dalam proses akulturasi yang dimaksudkan diatas sehingga didapati keberadaan adat serta budaya di daerah ini yang lebih fleksibel mengikuti perkembangan arus globalisasi tanpa meninggalkan ciri keasliannya.

Kepurbakalaan sebagai salah satu aspek budaya masa lampau pada kenyataannya banyak memberikan kontribusi keberadaan pendukungnya lewat berbagai tinggalan yang dikategorikan sebagai Benda Cagar Budaya dalam mewakili berbagai tingkat jaman dalam periodisasi arkeologi. Sejak periode Epipaleolitik hingga Kolonial telah banyak tercipta benda buatan manusia pendukung budaya tersebut sebagai pertanda kehadiran mereka sebagai salah satu komunitas masyarakat maupun sebagai bentuk ungkapan untuk mengekspresikan berbagai kegiatan ritual yang disesuaikan dengan konsep kepercayaan yang dianutnya sehingga didapati bahwa banyak tinggalan dapatlah mewakili suatu tingkat jaman yang dilalui dengan berbagai perkembangan yang mengarah kepada proses akulturasi yang dimajksudkan di atas, sehingga didapati beraneka ragam bentuk benda cagar budaya, baik yang bergerak maupun yang tidak bergerak yang memiliki informasi masa lampau dalam perkembangan masyarakat pendukung tradisi tertentu dengan seluruh aspek pembaharuannya, yang menunggu jamahan para arkeolog untuk mengungkap keberadaan informasi dimaksud guna mengetahui perkembangan kehidupan manusia masa lampau lewat berbagai benda peninggalannya yang secara kebetulan memiliki tingkat persebaran yang cukup merata di daerah Provinsi Maluku tercinta ini.

Subdin sejarah dan kepurbakalaan yang merupakan salah satu bagian dari Dinas Pendidikan dan Kebudayaan Provinsi Maluku yang bertugas untuk mengcover berbagai permasalahan kepurbakalaan di daerah Maluku dalam kenyataannya masih berjalan kurang maksimal karena berbagai hambatan yang ditemukan dalam pelaksanaan tugas dimaksud sehingga sampai dengan tahun 2007 melalui program inventasisasi hanya berhasil mengindentifikasikan 146 buah obyek BCB dengan spesifikasi Benda Tidak Bergerak serta 1.132 buah BCB yang merupakan Benda Bergerak.
Obyek yang merupakan Benda Tidak Bergerak walaupun sebagiannya memiliki juru pelihara namun secara keseluruhan terkesan kurang terawat sehingga dikhawatirkan disuatu saat nanti akan rusak dan tidak lagi memiliki nilai kepurbakalaan yang semestinya diemban oleh setiap obyek. Kendalakendala dalam pemeliharaan terlihat karena kurangnya tenaga juru pelihara yang dilibatkan sehingga mempengaruhi proses keterawatan suatu bentuk obyek kepurbakalaan, selain itu kurangnya pemahaman masyarakat sekitar obyek yang mendukung upaya pemeliharaan sehingga keberadaan tinggalan dimaksud haruslah diperhitungkan di tahun mendatang karena daerah Maluku dikenal sebagai daerah yang paling banyak tinggalan yang mewakili periodisasi kolonialnya.

Jumlah peninggalan yang merupakan Benda Cagar Budaya yang berhasil diidentifikasi antara lain benteng berjumlah 44 buah, kubu pertahanan sebanyak 21 buah, makam kuno berjumlah 10 buah, gereja kuno dengan jumlah 14 buah, mesjid kuno sebanyak 13 buah, monumen yang berjumlah 8 buah, situs dengan jumlah 20 buah, rumah kolonial sebanyak 12 buah, baileu serta rumah adat berjumlah 12 buah dan reruntuhan bangunan sebanyak 8 buah.

Tinggalan yang cukup variatif ini pada kenyataannya dari sisi pelestariannya sangat minim akan tindakan serta upaya yang dilaksanakan untuk mempertahankan keberadaan tinggalan-tinggalan dimaksud karena selama ini subdin Sejarah dan Kepurbakalaan baru dapat menyelesaikan 13 buah pemugaran dari keseluruhan peninggalan yang ada, itupun terjadi sebelum era otonomisasi dengan kekuatan anggaran pelaksanaan yang dihimpun dari pemerintah pusat melalui berbagai proyek APBN sedangkan sesudah otonomisasi ternyata didapati bahwa proses pemugaran terhadap sejumlah obyek yang merupakan aset budaya daerah yang telah mendapatkan prioritas untuk segera ditangani belumlah dapat dilaksanakan karena mengalami berbagai kendala di lapangan sehingga ikut menciptakan abrasi serta sejumlah kerusakan baru terhadap tinggalan-tinggalan dimaksud sehingga ditakutkan apabila hal ini dibiarkan terus menerus maka diasatu saat daerah ini akan kehilangan banyak tinggalan arkeologi sebagai pusat data masa lampau.

Kearifan lokal suatu masyarakat pendukung budaya masa lampau tentunya memiliki kaitan yang erat dengan peninggalan masa lampau yang berada di daerah dimana masyarakat dimaksud bermukim sehingga 
secara tidak langsung ikut menciptakan berbagai kebijakan sosial dalam pranata kehidupan yang terjalani dalam tatanan yang mendukung nilai kearifan itu sendiri. Biasanya nilai dimaksud tercermin dengan sendirinya lewat perkembangan adat yang dijalani sejak dahulu hingga sekarang yang memiliki hubungan timbal balik dengan berbagai tinggalan arkeologi yang disakralkan karena adanya talian adat yang dimaksudkan diatas.

Pada peninggalan kepurbakalaan seperti Baileu, rumah peribadatan serta situs-situs megalitik serta lainnya yang begitu disakralkan oleh masyarakat setempat dirasa akan mampu menggiring masyarakat dimaksud untuk tetap mengedepankan sikap sosial yang arif dalam hubungan kekerabatannya satu sama lain serta saling menghormato lewat konsep adat istiadat yang telah terbina sejak dahulu lewat pemahaman adanya konsepsi kepercayaan leluhur yang masih melekat dalam kehidupan mereka sehingga menciptakan kehidupan sosial yang bertendensi untuk tetap mengedepankan nilai-nilai kearifan lokal sebagai salah satu perkembangan kearah pelestarian berbagai peninggalan yang memiliki sentuhan sosial dengan bentuk nilai dimaksud sehingga mampu menciptakan suatu iklim pelestarian terhadap bentuk peninggalan yang berkaitan erat dengan konsepsi adat serta bentuk-bentuk pemujaan leluhur yang telah diyakininya sejak dahulu.

Upaya perlindungan dan pelestarian lewat konsep kearifan lokal yang terjalani dalam kehidupan masyarakat suatu daerah dimana tinggalan kepurbakalaan seperti yang disebutkan diatas berada akan terus bertahan selama tinggalan dimaksud mampu memberi panutan untuk menciptakan bentuk-bentuk kearifan yang dijalani masyarakat pendukungnya, dengan kata lain konsep adat istiadat suatu daerah akan selalu mampu untuk melindungi setiap tinggalan yang mampu mengkontribusikan nilai sosial yang arif dalam tatanan kehidupan masyarakat suatu daerah sebagai bentuk spontanitas dalam tatanan kehidupan sosial masyarakat daerah dimaksud, jadi pada beberapa jenis tinggalan yang memiliki kaitan erat dengan norma serta nilai kearifan lokal dalam tatanan masyarakat didapati bahwa proses pelestarian, perlindungan serta pemeliharaan akan selalu diprioritaskan oleh masyarakat dimaksud karena perkembangan adat istiadat di areal tersebut memang menghendaki upaya dimaksud.

Tinggalan jenis lainnya walaupun secara tidak langsung turut menandai perkembangan budaya dimana tinggalan tersebut berada namun keberadaannya turut memberikan kontribusi yang positif kearah perkembangan nilai kearifan lokal dalam suatu komunitas masyarakat biarpun didapati bahwa tinggalan dimaksud terkesan kurang terpelihara dan tidak terlindungi dengan baik sehingga membutuhkan perhatian dari pihak pemerintah baik di daerah maupun pemerintah pusat sehingga keberadaan tinggalan-tinggalan dimaksud dapatlah dilestarikan sebagai asset budaya daerah yang berpotensi dalam menunjang kepariwisataan daerah seribu pulau ini.

Upaya perlindungan dan pelestarian yang menjadi prioritas dalam berbagai kegiatan sesuai program kerja Subdin Sejarah dan Kepurbakalaan Dinas Pendidikan dan Kebudayaan Provinsi Maluku sejak bergabung dengan pemerintah, dipusatkan pada beberapa kegiatan yang akan diuraikan berikut ini sekaligus bersama kendala yang dijumpai dalam pelaksanaan kegiatan dimaksud serta upaya penanggulangannya sebagai berikut :

\subsection{Inventarisasi dan Dokumentasi}

Dalam program ini memuat beberapa kegiatan untuk melaksanakan pendataan terhadap Benda Cagar Budaya Bergerak maupun Tidak Bergerak sesuai dengan target yang diinginkan yaitu menambah jumlah BCB yang telah terdaftar diseluruh gugus pulau yang berada di daerah Provinsi Maluku. Dalam pelaksanaan kegiatan ini terdapat beberapa kendala antara lain :

$>$ Kurangnya pemahaman masyarakat akan arti, nilai serta fungsi Benda Cagar Budaya.

> Minimnya dana operasional untuk melaksanakan proses inventarisasi.

$>$ Kurangnya tenaga teknisi dalam melaksanakan kegiatan dimaksud.

\section{Upaya Penanggulangan:}

- Adanya kegiatan sosialisasi pengenalan BCB kepada masyarakatkeseluruh daerah persebaran khususnya pada lokasi tinggalanberada.

- Pengadaan dana hendaknya disesuaikan dengan daerah yang dituju 
- Tenaga teknisi diberi kesempatan untuk mendapatkan pelatihan secara teknis untuk menjamin validitasi data yang terhimpun

\subsection{Pemugaran}

Program ini memuat beberapa kegiatan yang berhubungan dengan proses pemugaran terhadap beberapa situs benteng pada beberapa gugus pulau dengan prioritas pada gugus pulau VI dan VII dengan mengadakan studi kelayakan sebagai dasar acuan kearah proses pemugaran obyek dimaksud. Permasalahan yang muncul sebagai kendala dalam pelaksanaan kegiatan tersebut diakibatkan karena :

- Kurangnya tenaga teknisi maupun arkeolog dalam menangani studi kelayakan serta tindak pemugaran terhadap obyek dimaksud.

- Minimnya dana yang disediakan untuk melaksanakan studi kelayakan maupun tindak pemugaran sehingga tidak mencapai target kerja sesuai program yang yang telah disepakati.

\section{Upaya Penanggulangan :}

- Menambah jumlah teknisi maupun arkeolog guna menunjang program subdin secara menyeluruh dan berkesinambungan.

- Mengusulkan penambahan dana studi kerlayakan serta pemugaran obyek dimaksud sesuai prioritas pengembangan sehingga tidak terjadi chaos dalam tindak lapangan seperti yang terjadi belakangan ini.

\subsection{Perlindungan}

Program perlindungan yang dilaksanakan memuat beberapa kegiatan pada beberapa daerah gugus dengan prioritas pada gugus pulau VI dan VII antara lain :

> Sosialisasi Undang-Undang Nomor 5 tahun 1992 ke daerah yang belum dijangkau pada kegiatan sebelumnya.

$>$ Mengeluarkan ijin pengeluaran $\mathrm{BCB}$ antar provinsi

$>$ Menginventarisir kasus pelanggaran.
Dalam pelaksanaan program ini didapati beberapa permasalahan sebagai berikut :

- Kegiatan sosialisasi belum menjangkau hingga ke daerah terpencil.

- Banyaknya BCB yang dibawah keluar provinsi tanpa ijin.

- Maraknya kasus pelanggaran yang terjadi akibat ketidak pahaman masyarakat.

\section{Upaya Penanggulangan :}

$>$ Menambah volume kegiatan sosialisasi secara merata di daerah tingkat II.

$>$ Menggiatkan kerjasama antar instansi terkait terutama Kepolisian.

$>$ Penempatan tenaga PPNS dalam pembinaan masyarakat sekitar obyek.

\subsection{Pemeliharaan}

Dalam program pemeliharaan didapati juga permasalahan mendasar yang merupakan kendala dalam pelaksanaan kegiatannya di seluruh gugus pulau sesuai keberadaan obyek antara lain :

$>$ Mengusulkan juru pelihara pada obyek yang diprioritaskan.

$>$ Mengusulkan penambahan jumlah obyek yang dipelihara mengingat banyaknya obyek yang masih terbengkalai.

> Meningkatkan kerjasama dengan daerah tingkat II dalam mengantisipasi pengadaan petugas keamanan atau satpam penjarpala pada obyek yang berpotensi menunjang dunia kepariwisataan di daerah dimaksud.

Dalam pelaksanaan kegiatan ini didapati beberapa permasalahan sebagai kendala antara lain :

- Jumlah juru pelihara tidak sebanding dengan jumlah situs sehingga menyebabkan banyak obyek yang terlantar.

- Banyak kasus pelanggaran yang dilakukan pada situs yang tidak memiliki juru pelihara.

- Minimnya honor juru pelihara

- Sarana dan prasarana pemeliharaan yang tidak memadai. 
- Tingkat pendanaan yang tidak memadai untuk menfasilitasi penempatan Satpam Penjarpala pada setiap situs.

\section{Upaya Panganggulangan:}

- Meningkatkan jumlah honor juru pelihara sebagai upaya untuk mendukung keberadaannya sebagai penjaga obyek purbakala.

- Menyediakan sarana dan prasarana pemeliharaan sesuai kebutuhan.

- Para juru pelihara diberi pelatihan secara berkala.

- Menciptakan pemerataan unsur pemeliharaan di seluruh obyek dengan menggalang kerjasama dengan daerah tingkat II maupun pihak swasta yang berminat.

\section{Penutup}

Program kerja Subdin Sejarah dan Kepurbakalaan Dinas Pendidikan dan Kebudayaan Provinsi Maluku sebagai istansi yang dipercayakan untuk membantu pemerintah untuk dalam mengelola, melestarikan berbagai peninggalan sejarah dan kepurbakalaan yang ada di daerah ini akan berjalan sesuai prioritas apabila adanya kerjasama antar instansi yang relevan serta munculnya animo masyarakat terutama pemilik tinggalan untuk tetap mempertahankan keberadaan tinggalan dimaksud sebagai asset budaya daerah yang berpotensi untuk merambah dunia kepariwisataan.

Khusus untuk jenis tinggalan yang memiliki keterkaitan dengan keberadaan adat istiadat di tempat tersebut akan selalu memberi nilai kearifan dalam tatanan kehidupan masyarakat pendukungnya selama fungsi sosialnya belum bergeser dan belum terjadi adanya perobahan yang mengarah kepada hilangnya nilai kearifan yang disandangnya.

Tugas kita semua sebagai pemerhati budaya di daerah ini haruslah mengacu kepada konsep pelestarian, perlindungan serta pemeliharaan yang telah dituangkan dalam Undang-Undang Nomor 5 tahun 1992 serta produk hukum lainnya yang mendukung undang-undang dimaksud sehingga bentuk serta nilai kearifan lokal bukannya hanya terpancar dari beberapa jenis tinggalan saja yang memiliki keterkaitan dengan adat setempat, tetapi juga terpancar dari keseluruhan tinggalan sebagai asset budaya masa lampau, dengan demikian daerah ini akan menjadi panutan untuk daerah lainnya bukan karena memiliki berbagai jenis tinggalan kepurbakalaan belaka tetapi karena kuatnya keinginan seluruh lapisan masyarakat untuk ikut melestarikan tinggalan-tinggalan dimaksud yang nantinya akan dibecking oleh pemerintah daerah dengan mengeluarkan perda yang mendukung keberadaan tinggalan tadi. 